\title{
BATERAI AIR LAUT SEBAGAI SUMBER ENERGI LISTRIK UNTUK PEMUKIMAN PESISIR DAN BUDIDAYA PERIKANAN
}

\author{
Eko Budi Santoso ${ }^{1}$, Mulyadi ${ }^{1.2}$ \\ 1, Jurusan Teknik Elektro Universitas Borneo Tarakan, Tarakan, Kalimantan Utara, Indonesia \\ 2. Divisi Teknologi Science Techno Park Kaltara, Tarakan, Kalimantan Utara, Indonesia \\ ${ }^{1}$ e-mail.ekob873egmail.com \\ ${ }^{2} e-m a i l . m u l y a d i a b o r n e o \cdot a c \cdot i d$
}

\begin{abstract}
Most of the needs of coastal communities and cultivators for electricity have not been served by electricity infrastructure providers. This paper aims to offer alternative solutions to overcome these problems through the use of seawater as a source of electrical energy that can be applied to small-scale applications in households in coastal areas and surrounding economic activities. This research has implemented a seawater battery with a combination of copper and magnesium electrodes and a DC-DC boost converter to increase the output voltage level. From the experimental results it is known that voltaic cells arranged in series give a series cell current density of $2.96 \mathrm{~A} / \mathrm{m}^{2}$ while parallel cell current density is only $0.0052 \mathrm{~A} / \mathrm{m}^{2}$. Similarly, the series cell power density was obtained at $24.57 \mathrm{~W} / \mathrm{m}^{2}$ while the parallel cell power density was only $0.396 \mathrm{~W} / \mathrm{m}^{2}$. The output voltage of each cell is $1.46 \mathrm{~V}$ and the maximum current is $183.2 \mathrm{~mA}$, each cell is capable of producing electrical power of $2.67 \times 10^{-3} \mathrm{~W}$. Ten cells arranged in series can produce a voltage of $13 \mathrm{~V}$. The converter produces unloaded voltage of $27.19 \mathrm{~V}$ but on the measurement of the voltage-loaded it decreases to only $8.1 \mathrm{~V}$. Voltaic cell power can last for 5 days in a unload condition and 8 hours if using a load.
\end{abstract}

Keywords-Sea water, battery, electricity, coastal.

Intisari-Kebutuhan masyarakat pesisir dan pembudidaya terhadap energi listrik sebagian besar belum dapat terlayani oleh penyedia infrastruktur kelistrikan. Makalah ini bertujuan menawarkan solusi alternatif untuk mengatasi persoalan tersebut melalui pemanfaatan air laut sebagai sumber energi listrik yang dapat diterapkan pada aplikasi skala kecil di rumah tangga kawasan pesisir maupun kegiatan ekonomi di sekitarnya. Penelitian ini telah menerapkan baterai air laut dengan kombinasi elektroda tembaga dan magnesium serta DC-DC boost converter untuk menaikkan level tegangan keluarannya. Dari hasil eksperimen diketahui bahwa sel volta yang disusun secara seri memberikan rapat arus sel seri sebesar $2,96 \mathrm{~A} / \mathrm{m}^{2}$ sedangkan rapat arus sel paralel hanya sebesar $0,0052 \mathrm{~A} / \mathrm{m}^{2}$. Demikian pula rapat daya sel seri diperoleh sebesar $24,57 \mathrm{~W} / \mathrm{m}^{2}$ sedangkan rapat daya sel paralel hanya sebesar $0,396 \mathrm{~W} / \mathrm{m}^{2}$. Beda potensial setiap sel sebesar $1,46 \mathrm{~V}$ dan arus maksimum sebesar $183,2 \mathrm{~mA}$, setiap sel mampu menghasilkan daya listrik sebesar $2,67 \times 10^{-3} \mathrm{~W}$. Sepuluh sel yang disusun seri mampu menghasilkan tegangan sebesar 13V. Hasil perancangan konverter menghasilkan tegangan tanpa beban sebesar $27,19 \mathrm{~V}$ namun pada pengukuran tegangan berbeban tegangan konverter menurun menjadi hanya 8,1V. Daya sel volta mampu bertahan selama 5 hari pada kondisi tanpa beban dan 8 jam jika menggunakan beban.

Kata Kunci-Air laut, baterai, listrik, pesisir.

\section{PENDAhuluaN}

Ketersediaan yang makin menipis serta isu kerusakan lingkungan [1-3] mendorong berbagai upaya untuk mencari sumber energi alternatif yang diharapkan mampu mengurangi ketergantungan terhadap bahan bakar fosil. Saat ini upaya pencegahan pemanasan global akibat emisi $\mathrm{CO}_{2}$ yang berasal dari bahan bakar fosil juga menjadi pertimbangan untuk mengurangi penggunaan bahan bakar fosil [4-7]. Salah satu alternatif yang terus dikembangkan oleh para peneliti adalah pemanfaatan air laut sebagai sel bahan bakar untuk membangkitkan tenaga listrik yang ramah lingkungan [8-11]. Penggunaan air laut sebagai sumber energi listrik belum dimanfaatkan secara optimal. Keberadaan listrik yang bersumber dari air laut merupakan solusi potensial dan murah untuk kebutuhan penerangan di sekitar pantai di mana listrik pemerintah sulit diakses. Namun, energi listrik yang dihasilkan dari sumber energi terbarukan selalu lebih sedikit dibandingkan dengan energi yang dihasilkan dari sumber tidak terbarukan. Masalah ini perlu diatasi jika energi terbarukan diharapkan untuk mensubsitusi energi konvensional. Mekanisme ekstraksi portabel untuk menghasilkan listrik perlu diteliti, terutama pengembangan purwarupa pemanenan energi dari air laut. Teknologi pemanfaatan atau pemanen energi saat ini semakin mendapatkan perhatian untuk energi bersih dan berkelanjutan, terutama untuk aplikasi seperti internet, perangkat seluler, implan biomedis dan jaringan sensor nirkabel [12]. Dibandingkan dengan sistem energi terbarukan yang menggunakan energi skala besar seperti energi matahari, angin, pasang surut, dan geo-termal, teknologi pemanenan energi mengekstraksi secara signifikan daya dan energi kecil dari sumber-sumber sekitar yang sebagian besar telah terbuang seperti, energi panas tingkat rendah dari panas yang terbuang [13], energi mekanik dari getaran struktural [14], energi magnetik dari gelombang frekuensi radio [15] atau saluran transmisi AC [16], energi elektrostatik dari kapasitor yang tergantung getaran [17], energi cahaya dari komunikasi cahaya tampak [18] dan energi kimia dari air limbah. Upaya memanfaatkan energi yang dipanen dari sumber sekitar menjadi lebih dimungkinkan karena perangkat elektrik portabel dan sensor-sensor saat ini kebanyakan dirancang hanya membutuhkan arus listrik yang rendah. Berbagai perangkat yang mengubah energi dari sumber sekitar tersebut secara langsung menjadi listrik telah dikembangkan seperti generator termoelektrik 
menggunakan gradien termal [19], perangkat piezoelektrik menggunakan deformasi mekanik [20], rectenna dengan dioda RF [21], bahan electret [22], sel bahan bakar mikroba untuk proses respirasi bakteri [23]. Sumber energi ini umumnya memiliki kerapatan daya yang sangat rendah di kisaran 10-100 $\mu \mathrm{W} / \mathrm{cm} 2$ [24], sehimgga diperlukan pemanen energi yang mampu meningkatkan tegangan ke level yang lebih tinggi agar dapat dengan mudah berinteraksi dengan perangkat elektronik yang umum digunakan oleh masyarakat. Secara keseluruhan, ada lonjakan minat dalam pemanenan energi dari air laut karena

\begin{tabular}{|l|l|}
\hline$V_{\text {in }}($ Min) & 0,7 Volt \\
\hline$V_{\text {in }}($ Max) & 1 Volt \\
\hline$V_{\text {out }}$ & 12 Volt \\
\hline I out & 0,25 Ampere \\
\hline
\end{tabular}
potensinya yang sangat besar. Namun karena kurangnya informasi dan teknologi yang belum tersedia, penelitian di bidang ini perlu mendapat perhatian lebih seksama. Makalah ini bertujuan untuk meninjau proses produksi listrik dari air laut serta untuk mengidentifikasi kemungkinan implementasi pada masyarakat pesisir dan pembudidaya untuk mendorong terwujudnya budidaya yang ramah lingkungan.

\section{METODE PENELITIAN}

\section{A. Perancangan Sel Volta}

Sebanyak 10 sel volta dipersiapkan untuk mendukung eksperimen, sel volta tersebut di isi dengan suatu cairan dengan komposisi terdiri dari aquades sebanyak $2000 \mathrm{ml}$ yang dicampur dengan garam sebanyak 175 gram. Cairan ini akan berfungsi sebagai larutan elektrolit. Pada setiap sel ditempatkan sepasang elektroda logam berupa pelat tembaga $(\mathrm{Cu})$ dan pelat magnesium $(\mathrm{Mg})$ dengan spesifikasi penampang setiap elektroda memiliki panjang 7 $\mathrm{cm}$ dan lebar $3 \mathrm{~cm}$. Sel-sel ini akan terintegrasi pada suatu wadah yang memiliki dimensi panjang sebesar $20 \mathrm{~cm}$ dan lebar sebesar $14 \mathrm{~cm}$. Ilustrasi rancangan sel volta ditunjukkan pada gambar 1 .

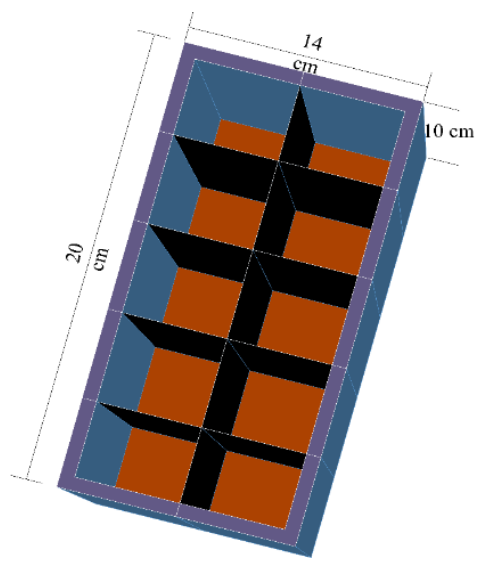

Gambar 1. Penampang wadah sel volta

\section{B. Spesifikasi Perancangan}

Perancangan didasarkan pada sumber daya pada sel volta. Beda potensial listrik minimal sebesar 0,8 Volt dan tertinggi sekitar 1 Volt. Beda potensial listrik dan arus keluaran di harapkan dapat mencapai daya $3 \mathrm{~W}$, sehingga dapat menyalurkan beban sebesar $48 \Omega$. Duty cycle sebesar 0,953 sedangkan penguatan konverter sebesar 14.89 Volt. Estimasi induktor sebesar $7,624 \mu \mathrm{H}$. Pada penelitian ini menggunakan toroid dengan spesifikasi T157-2 maka jumlah lilitan sekitar 23 lilitan. Hasil perancangan konverter menghasilkan tegangan tanpa beban sebesar $27,19 \mathrm{~V}$, namun pada pengukuran tegangan menggunakan beban tegangan konverter menurun menjadi $8,1 \mathrm{~V}$.

Tabel I.

Spesifikasi perancangan konverter

\section{Pengujian Perangkat}

Sel volta yang telah dibuat, kemudian dihubungkan dengan perangkat konverter yang akan diukur daya keluaran besaran listrik untuk sel volta yang disusun seri dan paralel, serta besaran listrik pada saat perangkat diberi beban dan tanpa beban.

\section{HASIL DAN PEMBAHASAN}

\section{A. Hasil Pengujian Pada Sel Volta}

Hasil pengujian sel volta, dicantumkan pada Tabel II

Tabel II

Hasil pengukuran pada sel volta

\begin{tabular}{|l|c|c|}
\hline \multicolumn{1}{|c|}{ Parameter } & Seri & Paralel \\
\hline Arus input & $64,7 \mathrm{~mA}$ & $7,1 \mathrm{~mA}$ \\
\hline Tegangan input & $1,36 \mathrm{~V}$ & $0,506 \mathrm{~V}$ \\
\hline Arus output & $6,22 \mathrm{~mA}$ & $0,11 \mathrm{~mA}$ \\
\hline $\begin{array}{l}\text { Tegangan } \\
\text { output }\end{array}$ & $8,3 \mathrm{~V}$ & $7,56 \mathrm{~V}$ \\
\hline Daya Output & $0,0516 \mathrm{~W}$ & $0,8316 \mathrm{~mW}$ \\
\hline
\end{tabular}

Dari Tabel II dapat diketahui perbandingan nilai tegangan dan arus yang dihasilkan 10 sel volta yang disusun seri dan paralel, beda potensial tiap sel volta sebesar 1,46 Volt. Daya luaran yang dihasilkan oleh sel volta tersusun seri sebesar $0,0516 \mathrm{~W}$ sedangkan daya luaran yang dihasilkan oleh sel volta yang tersusun paralel sebesar $0,8316 \mathrm{~mW}$. Dari tabel tersebut terlihat bahwa sel volta yang disusun seri memiliki nilai tegangan dan arus yang lebih besar dibandingkan sel volta yang disusun paralel, hal ini karena pada sel volta paralel tidak mampu menyalakan beban sehingga arus yang terukur lebih kecil dibandingkan sel volta yang tersusun seri.

\section{B. Hasil Perhitungan Rapat Daya dan Rapat Arus}

Hasil perhitungan rapat arus sel seri Rapat arus $=\mathrm{I} / \mathrm{A}$;

$$
=0,000622 / 0,0021 ;=2,96 \mathrm{~A} / \mathrm{m}^{2}
$$

Hasil perhitungan rapat arus sel paralel

Rapat arus $=\mathrm{I} / \mathrm{A}$

$$
=0,00011 / 0,0021 ;=0,0052 \mathrm{~A} / \mathrm{m}^{2}
$$

Hasil perhitungan rapat daya sel seri

Rapat daya $=$ I /A;

$$
=0,0516 / 0,0021 ;=24,57 \mathrm{~W} / \mathrm{m}^{2}
$$


Hasil perhitungan rapat daya sel paralel

Rapat daya $=$ I /A;

$$
=0,0008316 / 0,0021 ;=0,396 \mathrm{~W} / \mathrm{m}^{2}
$$

\section{Hasil Perhitungan Konverter}

Hasil perhitungan konverter ditunjukan pada tabel III

Tabel III

Hasil Perhitungan Konverter

\begin{tabular}{|l|l|l|}
\hline Parameter & Seri & Paralel \\
\hline Tahanan beban & $1334,4 \Omega$ & $68727,2 \Omega$ \\
\hline Duty cycle & 0,868 & 0,946 \\
\hline Daya & $0,0516 \mathrm{~W}$ & $0,8316 \mathrm{~mW}$ \\
\hline
\end{tabular}

Kapasitas daya tiap sel memiliki beda potensial sebesar 1,46 $\mathrm{V}$ dan arus maksimum sebesar 183,2 mA, sehingga daya yang dihasilkan tiap sel adalah sebagai berikut.

$$
\begin{aligned}
P & =V \times I \\
& =1,46 \times 0,8132 \\
& =0,267 \mathrm{~mW}
\end{aligned}
$$

\section{Daya Tahan Sel Volta}

Sel volta memiliki ketahanan terbatas, elektroda akan terkorosi karena pengaruh ion garam. Magnesium akan melepaskan elektron sehingga magnesium akan meluruh dan larut dengan sendirinya, sedangkan elektroda tembaga akan menerima elektron sehingga elektroda tembaga akan mengalami korosi. Dari pengamatan pada saat eksperimen diketahui bahwa daya tahan sel volta yang disusun seri dan paralel adalah 5 hari, sedangkan jika menggunakan pembebanan maka sel hanya mampu bertahan selama 8 jam. Sepuluh sel yang disusun seri mampu menghasilkan tegangan sebesar $13 \mathrm{~V}$, semakin banyak sel yang disusun seri, maka semakin besar tegangan yang dihasilkan. Berikut adalah kurva rapat arus dan rapat daya yang dihasilkan oleh sel volta pada eksperimen.

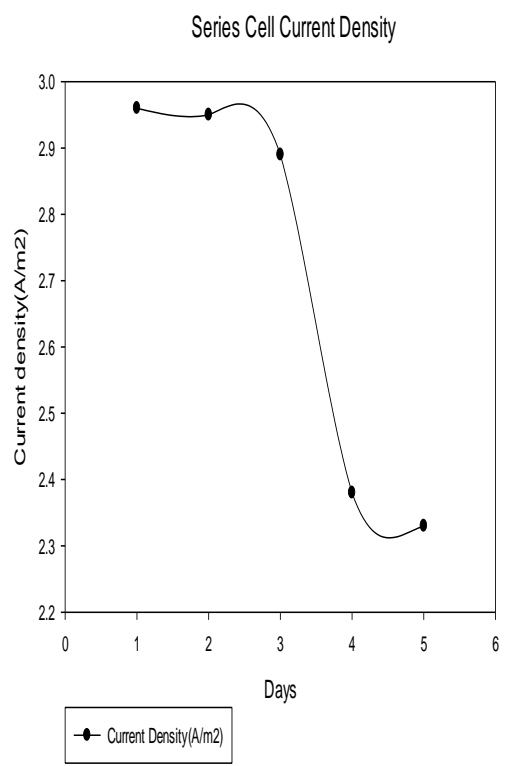

Gambar 2. Kurva rapat arus sel seri

Pada gambar 2 ditunjukkan bahwa pada hari ke-1 sel volta mampu menghasilkan rapat arus sebesar $2,96 \mathrm{~A} / \mathrm{m}^{2}$ yang kemudian mengalami sedikit penurunan pada hari ke-2 menjadi $2,95 \mathrm{~A} / \mathrm{m}^{2}$ selanjutnya menjadi $2,89 \mathrm{~A} / \mathrm{m}^{2}$ pada hari ke-3 lalu menurun menjadi $2,38 \mathrm{~A} / \mathrm{m}^{2}$ pada hari ke-4 hingga akhirnya menjadi $2,33 \mathrm{~A} / \mathrm{m}^{2}$ pada hari ke-5.

Parallel Cell Current Density(A/m2)

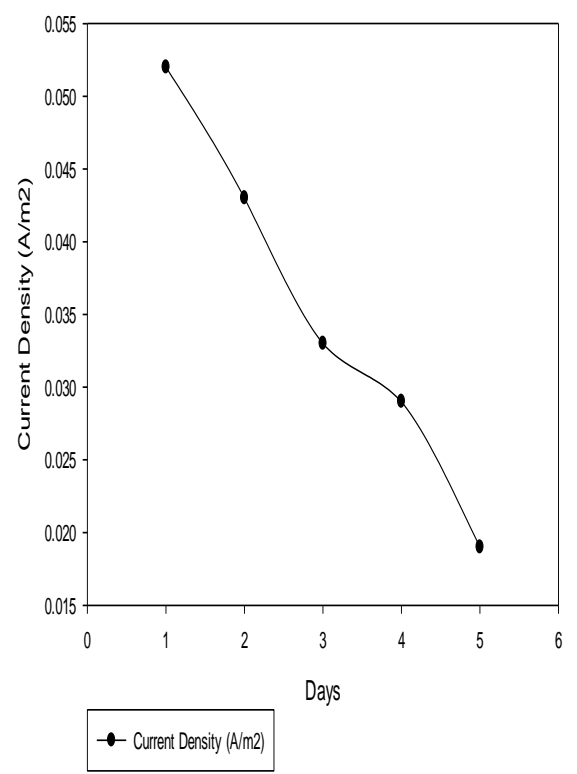

Gambar 3. Kurva rapat arus sel paralel

Sel volta juga disusun dengan konfigurasi paralel. Gambar 3 menunjukkan kurva hasil pengukuran rapat arus yang diperoleh. Hari ke-1 tercatat rapat arus yang dihasilkan sebesar $0,052 \mathrm{~A} / \mathrm{m}^{2}$ yang kemudian juga mengalami penurunan berturut-turut sejak hari ke-2 menjadi $0,043 \mathrm{~A} / \mathrm{m}^{2}$ kemudian menurun menjadi $0,033 \mathrm{~A} / \mathrm{m}^{2}$ untuk hari ke-3 lalu pada hari ke-4 turun menjadi sebesar $0,029 \mathrm{~A} / \mathrm{m}^{2}$ hingga pada hari ke-5 tercatat sebesar $0,019 \mathrm{~A} / \mathrm{m}^{2}$.

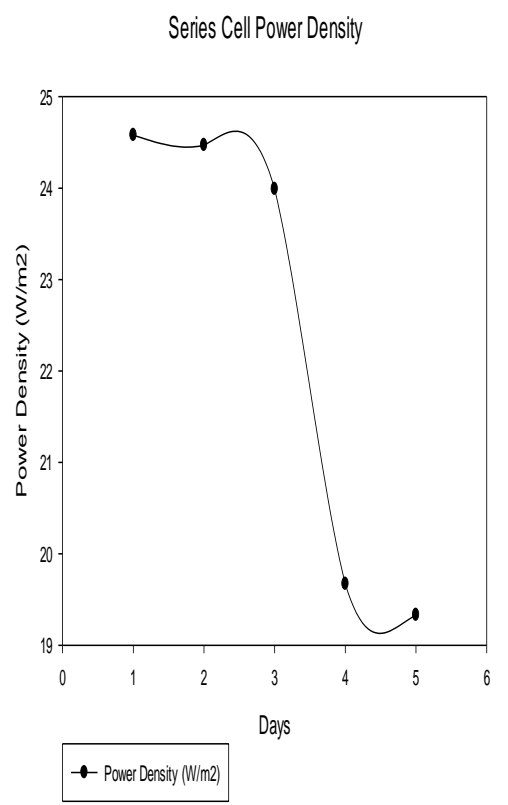

Gambar 4. Kurva rapat daya sel seri

Gambar 4 menampilkan kurva nilai rapat daya sel volta yang tersusun seri sejak hari ke-1 sebesar $24,58 \mathrm{~W} / \mathrm{m}^{2}$ sedikit menurun menjadi $24,47 \mathrm{~W} / \mathrm{m}^{2}$ pada hari $\mathrm{ke}-2$ lalu menjadi $23,99 \mathrm{~W} / \mathrm{m}^{2}$ pada hari ke-3 selanjutnya 
kembali menurun menjadi sebesar $19,76 \mathrm{~W} / \mathrm{m}^{2}$ pada hari ke-4 hingga akhirnya tercatat sebesar 19,33W/m² pada hari ke-5.

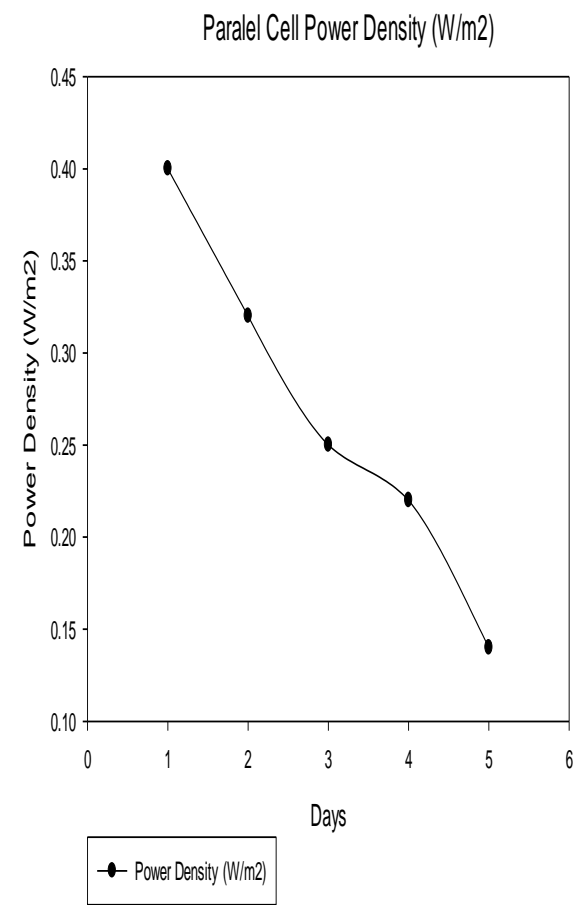

Gambar 5. Kurva rapat daya sel paralel

Hasil pengukuran rapat daya sel volta tersusun paralel disajikan oleh Gambar 5 yang juga menunjukkan kecenderungan penurunan setelah pada hari ke-1 tercatat sebesar $0,40 \mathrm{~W} / \mathrm{m}^{2}$ maka pada hari $\mathrm{ke}-2$ menurun menjadi $0,32 \mathrm{~W} / \mathrm{m}^{2}$ lalu menurun kembali menjadi $0,25 \mathrm{~W} / \mathrm{m}^{2}$ pada hari ke-3, selanjutnya mengalami penurunan kembali pada hari ke-4 menjadi sebesar $0,22 \mathrm{~W} / \mathrm{m}^{2}$ hingga akhirnya tercatat pada hari ke-5 nilai rapat daya sebesar $0,14 \mathrm{~W} / \mathrm{m}^{2}$.

\section{KESIMPULAN}

Pengamatan dari implementasi sel volta yang tersusun secara seri dan paralel pada sistem baterai air laut ini diantaranya adalah rangkaian konverter yang telah dibuat lebih cocok digunakan pada sel volta yang tersusun secara seri, hal ini tampak dari pengujian sel volta yang disusun secara seri memberikan rapat arus sel sebesar 2,96 A/m² sedangkan rapat arus sel paralel hanya $0,0052 \mathrm{~A} / \mathrm{m}^{2}$. Demikian pula rapat daya sel seri diperoleh sebesar 24,57 $\mathrm{W} / \mathrm{m}^{2}$ sedangkan rapat daya sel paralel hanya $0,396 \mathrm{~W} / \mathrm{m}^{2}$ sehimgga menghasilkan cahaya LED yang lebih terang daripada sel volta yang tersusun secara paralel. Desain konverter sesuai untuk menguji konverter tanpa beban, dengan beda potensial setiap sel sebesar 1,46 V dan arus maksimum sebesar 183,2 mA, maka setiap sel mampu menghasilkan daya sebesar $2,67 \times 10^{-3} \mathrm{~W}$. Sepuluh sel yang disusun seri mampu menghasilkan tegangan sebesar $13 \mathrm{~V}$, namun tegangan keluaran konverter akan menurun secara eksponensial ketika dibebani, sehingga daya tahan sel seri dan paralel adalah 5 hari dalam kondisi tanpa beban dan jika mendapat pembebanan maka sel volta dapat bertahan hingga 8 jam sebelum elektroda terkorosi dan mengalami peluruhan massa, walaupun demikian kombinasi elektroda tembaga dan magnesium terbukti mampu menghasilkan energi listrik lebih besar daripada elektroda jenis lain. Penyesuaian rancangan rangkaian konverter daya dan sel baterai diperlukan untuk mendapatkan hasil optimal yang sesuai dengan kebutuhan pengguna.

\section{UCAPAN TERIMA KASIH}

Terima kasih disampaikan kepada Ibu Rika Wahyuni Arsianti, S.T., M.T dan Ibu Raudhah, S.T., Sp.d yang telah memfasilitasi penyelesaian penelitian ini sejak proses penyusunan proposal hingga akuisisi data dan penyusunan artikel ini.

\section{REFERENSI}

[1] Alamaro M Nature. 514 7. 2014.

[2] Schiermeier O Nature. 514 10-11. 2014.

[3] Hartmann A, Gleeson T, Wada Y, Wagener T Proc. Natl. Acad. Sci. 114 2842-2847. 2017.

[4] Kamat P V Acc. Chem. Res. 50 527-531. 2017

[5] Yuan Y J, Yu Z T, Chen D Q, Zou Z G Chem. Soc. Rev. 46 603-631. 2017

[6] Christoforidis K C, Fornasiero P Chem.Cat.Chem. 9 15231544. 2017

[7] Bae D, Seger B, Vesborg P C K, Hansen O, Chorkendorff I Chem. Soc. Rev. 46 1933-1954, 2017.

[8] Wilcock W, Kaufman P, Development of seawater battery for deep-Water applications J. Power Sources. 66 71. 1997

[9] Park S, B Senthil Kumar, K Kim, SM Hwang and Y Kim. Saltwater as The Energy Source for Low Cost, Safe Rechargeable Batteries. Journal Material Chemistery A. 4 (19):7207-7213. 2016.

[10] Chu J The power of salt. MIT Study investigates power generation from the meeting of river water and seawater. 2014.

[11] Tedesco M, Cipollina A, Tamburini A and Micale G Towards $1 \mathrm{~kW}$ power production in a reverse electrodialysis pilot plant with saline waters and concentrated brines Journal of Membrane Sci 2017. vol 522 pp 226.

[12] J.A. Paradiso, T. Starner, Energy scavenging for mobile IEEE Pervasive Computing 4 (1) (Jan 2005) 18-27.

[13] M. Reznikov, P. Wilkinson, Electric power generation at low temperature gradients, IEEE Trans. Ind. Appl. 50 (6) (Nov 2014) 4233-4238.

[14] R. Dayal, S. Dwari, L. Parsa, Design and implementation of a direct AC-DC boost converter for low-voltage energy harvesting, IEEE Trans. Ind. Electron. 58 (6) (June 2011) 2387-2396.

[15] J. Liu, K. Xiong, P. Fan, Z. Zhong, RF energy harvesting wireless powered sensor networks for smart cities, IEEE Access 5 (May 2017) 9348-9358.

[16] T. Hosseinimehr, A. Tabesh, Magnetic field energy harvesting from AC lines for powering wireless sensor nodes in smart grids, IEEE Trans. Ind. Electron. 63 (8) (Aug 2016) 4947-4954.

[17] E.O. Torres, G.A. Rincon-Mora, Electrostatic energyharvesting and battery-charging CMOS system prototype, IEEE Transactions on Circuits and Systems I: Regular Papers 56 (9) (Sept 2009) 1938-1948.

[18] T. Rakia, H.C. Yang, F. Gebali, M.S. Alouini, Optimal design of dual-hop VLC/RF communication system with energy harvesting, IEEE Commun. Lett. 20 (10) (Oct 2016) 1979-1982.

[19] M. Bond, J.D. Park, Current-sensorless power estimation and MPPT implementation for thermoelectric generators, IEEE Trans. Ind. Electron. 62 (9) (Sept 2015) 5539-5548.

[20] G.K. Ottman, H.F. Hofmann, A.C. Bhatt, G.A. Lesieutre, Adaptive piezoelectric energy harvesting circuit for 
wireless remote power supply, IEEE Trans. Power Electron. 17 (5) (Sep 2002) 669-676.

[21] C. Song, Y. Huang, J. Zhou, P. Carter, S. Yuan, Q. Xu, Z. Fei, Matching network elimination in broadband rectennas for high-efficiency wireless power transfer and energy harvesting. IEEE Trans. Ind. Electron. 64 (5) (May 2017) 3950-3961.

[22] E.R. Westby, E. Halvorsen. Design and modeling of a patterned-electret-based energy harvester for tire pressure monitoring systems. IEEE ASME Trans. Mechatron. 17 (5) (Oct 2012) 995-1005.

[23] Mulyadi and R. W. Arsianti, "Low Power Electrical Generator from Soil Microbial Fuel Cell," 2018 Electrical Power, Electronics, Communications, Controls and Informatics Seminar (EECCIS), Batu, East Java, Indonesia, 2018, pp. 85-89, doi: 10.1109/EECCIS.2018.8692948.

[24] S. Boisseau, G. Despesse, B.A. Seddik, Electrostatic conversion for vibration energyharvesting, in: M. Lallart (Ed.), Small-Scale Energy Harvesting, Intech, 2012. 